\title{
Does Direct Instruction Develop Pragmatic Competence? Teaching Refusals to EFL Learners of English
}

\author{
Majid Farahian \\ Department of Foreign Languages, Kermanshah Branch, Islamic Azad University, Kermanshah, Iran \\ Email: majid_fa53@yahoo.com \\ Mehrdad Rezaee \\ Department of Foreign Languages, Central Tehran Branch, Islamic Azad University, Tehran, Iran \\ Email: mehr351@yahoo.com \\ Afshin Gholami \\ Razi University, Kermanshah, Iran
}

\begin{abstract}
To achieve communicative competence, L2 learners' need to develop their pragmatic competence and this may be fostered with the help the learners receive from their teachers. This paper is an attempt to investigate the efficacy of explicit instruction of refusal at pragmatic level to four types of acts- invitations, suggestions, offers and requests. Adopting a pretest/posttest design as with treatment and control group, the two groups in this study were exposed to the treatment. Data collected by means of written Discourse Completion Test (DCT) as well as written self report suggest that the instructional approach resulted in gain in L2 pragmatic ability of the experimental group. The delayed posttest used in the study confirmed the findings. The findings may contribute to the interlanguage pragmatic pedagogy, especially in the EFL context and suggest that meta-pragmatic information the $L 2$ learners received through pedagogy may lead to learners' $L 2$ pragmatic development.
\end{abstract}

Index Terms - pragmatics, pragmatic competence, explicit instruction, refusals

After long years of equating second language learning with linguistic accuracy, there is now a general consensus that while grammatical competence is an integral part of language competence, it cannot be equated with grammatical knowledge. Based on different models of communicative competence proposed in the history of applied linguistics in order to be communicatively competent a second language learner needs something more than grammatical knowledge. With the redefinition of the communicative competence and inception of communicative approach, primary importance was given to the functional abilities in the second language. This functional ability has the purpose of understanding and producing language that is appropriate to communicative situations in accordance with specific sociocultural factors (Rueda, 2006). Meanwhile, there is the issue of pragmatic competence as another aspect of communicative competence which is concerned with factors affecting the meaning of utterances produced by interlocutors. Pragmatic competence is defined as knowledge of communicative action, how to carry it out, and the ability to use language appropriately according to contextual factors (Kasper, 1997). It is believed that whenever there is a failure to observe these parameters communication breakdowns or misunderstanding may occur (Thomas, 1983). Therefore, in case of second language learners' their utterances may be regarded as meaningless or rude.

Non-native speakers of a language do not often demonstrate their capability of using such ability and it has been suggested that explicit pragmatic instruction be incorporated in the second language curricula to help second language learners with the deficiency (e.g. Vásquez et al., 2009). This includes both pragmalinguistics and sociopragmatics as the two areas of pragmatics which should be acquired by second language learners for the purpose of achieving full communicative competence in a target language.

Justification for direct instruction has been provided with cognitive psychology. The prevalent assumption of 1980's that language learning can take place without some degree of consciousness is not theoretically viable and hotly debated (Nassaji and Fotos, 2004). Based on Ellis (2008), the role of unconscious learning has been exaggerated in this decade neglecting the fact that conscious attention to form, or what has been called "noticing" is a necessary condition for language learning (Nassaji and Fotos 2004). According to Schmidt (1995), acquisition must entail awareness and that "learning requires awareness at the time of learning" (p. 26). To stress the importance of consciousness, Schmidt (1995) also states that "whatever is noticed in the input will become intake for learning" (p. 20), whether this noticing is unintentional or deliberate; if it is noticed it will become intake. (Schmidt, 1995). It is such view of noticing which may provide the rationale for the explicit teaching of pragmatics in second language context. 
Instructional suggestions as to the role of pragmatics have also been supported by scholars such as Kasper \& Schmidt (1996) and Bardovi-Harlig (1999). Rueda (2006) holds that the findings of such studies back up the assumption about the positive effect of pedagogical intervention, and, as he maintains, "in this way the view that pragmatic ability can be systematically developed through planned classroom activities" (p. 170). Kasper \& Rose (2001) also refer to different current studies which have aimed at investigating learners' use and acquisition of L2 pragmatic ability mention that the findings suggest that pragmatic ability can be taught. (Yoshimi, 2001).

It is assumed that second language contexts is more advantageous than foreign language settings for learning pragmatic rules this is, as Kasper (2001) notes, learners in a second language context are fully exposed to the target language in the real-life situation and they have opportunity to use it in the appropriate contexts. As Martinez-Flor and Uso Juan (2006) note "[T]his fact allows them to develop their pragmatic ability, since they may become involved in situations where they are required to interpret utterances in context or interact with a variety of participants in different environments" (p. 51). Contrary to second language learners in the real-life context, learners who are learning the language in a foreign language context do not have the chance to get involved in communicative situations in order to fully develop their language competence. Furthermore, they rarely have the opportunity to see native speakers communicating in their language. Therefore, creating conditions to developing learners' pragmatic competence is not only necessary for both those who are studying the foreign language contexts, but also for the learners in the second language context. Martinez-Flor and Uso Juan (2006) put it in this way

Indeed, in spite of all the advantages that these particular settings may offer for pragmatic development, it has been claimed that, even after a long period of contact with the target language, some pragmatic aspects still continue to be incomplete (p. 51).

It should be mentioned that pragmatic competence is not just synonymous with appropriate use of language. Brock and Nagasaka (2005) explain what pragmatic competence includes by saying that,

[it] encompasses a variety of abilities in the use and interpretation of language in context.... These include a speaker's ability to use language for different purposes (such as greeting, requesting, informing, demanding and so on), the speaker's ability to adapt or change language according to the needs or expectations of the listener or situation, and the speaker's ability to follow accepted rules; the maxims, if you will, for conversation and narrative. (p. 19).

In this sense, a growing body of research has focused on the importance of pragmatics in second language acquisition. A substantial body of these studies has demonstrated that there is a need for explicit pragmatics instruction. For example, Tanaka (1997) found that in order to gain mastery of communicative competence, L2 learners have to acquire pragmatic competence. In a similar study, Koike (1997) concluded that although adult second language learners have gained a satisfactory command of the L2 grammatical and lexical knowledge, they are often not able to produce pragmatically appropriate utterances.

One of the sensitive pragmatic issues, among others, is the refusal involved in daily communication of native speakers. In refusal situations a variety of forms are employed. If second language learners are not familiar with different ways of offering refusals, their addresses in the second language context may misunderstand them. But what is refusal? As Al-Kahtani (2005) explains "a refusal is to respond negatively to an offer, request, invitation, etc." (p. 3). He adds that "since expressing 'no' is not easy for non-native speakers, how one says 'no' is more important in many societies than the answer itself" (p. 3). Lingli and Wannaruk (2010) refer to Brown \& Levinson (1987) who define refusal as "a face-threatening and affectively negative speech act and can be characterized as a response to another's act (e.g., request, invitation, offer, suggestion), rather than as an act initiated by the speaker" (p. 94). They are considered to be face threatening since the listener's or speaker's positive or negative face is at risk whenever a refusal is called for or carried out. Lingli and Wannaruk maintain that since refusals are typically used by the second pair in the interaction, preplanning for them is not possible and demanding. This makes them more sensitive and complicated to be incorporated in an instructional course.

Related literature shows that a few studies have dealt with the explicit instruction of refusals in English (i.e., King \& Silver, 1993; Morrow, 1995; Silva, 2003) especially in foreign language context. The main feature of the studies conducted on explicit teaching of pragmatics is that the instructional time is relatively short. Moreover, none of these studies employed control group in their design. The teaching procedures in different studies on the issue also vary, and such variation may have contributed to different results of the studies. Furthermore, to the authors' knowledge, nearly all of these studies are just of qualitative design.

Due to the delimitations of the studies carried out on refusals in the English language and because of the fact that such studies in the English as a Foreign Language (EFL) context, especially in the context of Iran is quite limited, the present study was carried out with the purpose of investigating the effect of teaching refusals explicitly to Iranian University students. Therefore, the question to be answered was as follows:

1. Does explicit instruction have a significant impact on Iranian EFL learners' production of linguistically accurate and pragmatically appropriate requests?

\section{METHOD}

\section{A. Participants}


The participants in this study were 64 Iranian intermediate university students, age, 19-25. Because the necessity of working with intact groups makes random assignment impossible, the research was an intervention study; therefore, it was quasi-experimental.

\section{B. Instructional Targets}

Different kinds of English refusals have been found. These refusals, based on Lingli and Wannaruk (2010) include four types: refusing suggestions, refusing invitations, refusing requests, and refusing offers. Each type of these refusals has different kinds of statuses. For example, refusing a person of higher status differs from refusing a person of lower status. The instructional targets in this study were manly chosen from Wannaruk (2008). Based on Wannaruk refusal strategies are classified based on refusal types, refuser statuses, and refusals strategies. "I'll be doing my homework that night." is an example for "explanation" strategy.

\section{The Instruction}

To investigate the research question, an explicit instruction was used I the study. Following Yoshimi (2001), the following steps were taken to teach pragmatics to learners.

1. Presentation of learning targets:

a. Learners listen to the dialogue in which segment of the speech act-here refusal-is embedded.

b. Learners answer some questions which are meaning focused.

2. Explaining learning targets:

a. Teacher explaining explicitly about the function and use of refusal strategies

b. Teacher leading a discussion and comparison of Farsi and American English refusals strategies

3. Planning sessions

a. Learners planning the production nonformal, extended discourse

b. Learners listening to the dialogues again

c. Learners preparing for role play based on the situation in the dialogues

d. Learners working in pairs

e. Teacher offering an explicit use in refusal strategies whenever learners need

4. Communication session

a. Learners having communicative practice of the target items in conjunction with extended discourse

b. Teacher selecting several pairs to act out the dialogue

5. Feedback

a. Corrective feedback: providing feedback on the use of target items and the production of extended discourse

b. Teacher correcting explicitly any inappropriate use

The most important stage of the instruction is explaining learning targets. Based on this stage, the function and use of refusal strategies was explained by the teacher and later refusal strategies were compared in the source and target languages (Lingli and Wannaruk, 2010). The second stage which was of a great importance was the feedback stage which led the participants create their utterances using the speech acts. This was followed by the teacher's necessary correction of inappropriate utterances made by the students.

\section{PROCEDURE}

The experimenter randomly assigned the 64 participants to one of two experimental and control group. The two groups were tested with a pretest and a posttest. The pretest was conducted two weeks prior to treatment. The posttest was conducted one day after the treatment and the posttest two weeks after the posttest. Both the pretest, posttest and the delayed posttest were the same written Discourse Completion Task (DCT) (see Appendix). The DCT was adapted from a study by Lingli and Wannaruk (2010). There were some necessary changes in the questionnaire; some items were deleted and substituted with those which were in line with the purpose of the study and some ambiguous ones were paraphrased. DCT items typically include a situational description which is followed by a brief dialogue. In these kinds of tests, the participant is required to complete an open slot so that a specific communicative act is elicited.

To answer the test, 30 minutes time was given to the participants. However, when they found any point unclear, they could ask the teacher for help.

There were four aspects of appropriacy as rating criteria and the analytic Likert 5 for marking was employed. Therefore, the scale of 5 indicates "completely appropriate"; the scale of 4 refers to "mostly appropriate"; the scale of 3 as "generally appropriate"; the scale of 2 means "not very appropriate but acceptable"; the scale of 1 indicates "not appropriate and not acceptable".

For the DCT scoring, two bilingual English speaking ELT teachers residing in Iran were chosen.

To confirm participants' answers to the written DCT (Kasper \& Rose, 2002) and in order to triangulate the data, a written self report was conducted after the delayed posttest. The self report was taken from Duan (2008) and modified. These reports presented learners' views of the appropriateness of refusals they had been instructed (See the Appendix). The self report consisted of four questions and participants were required to answer the questions either in Farsi. 
To categorize the self-report data the following steps were taken. Firstly, the participants were allowed to answer the questions either in Farsi or English. Secondly every single opinion was identified in detail. Thirdly, the researcher was careful to find the differences and similarities between the participants' statements in order to classify them. Fifthly, these statements were grouped roughly into different categories and finally, the conclusions were drawn from the categories made.

\section{RESULTS}

If we take a look at Table 1 which is named "Descriptive statistics of the pre-test taken by both control and experimental groups", we will realize that the difference between the two groups regarding their mean and SD is not significant. As we see, the SD of Control Group Pre-test is 2. 75897 and the SD of Experimental Pre-test is 2.99395. The range in both of them is 10 and their mean is approximately the same (Control Group Pre-test Mean is 14.5313 and Experimental Pre-test Mean is 14.5625). Nevertheless, if we see Table 2., we will realize that in Post-Test Control Group Standard Deviation is 2.29919 while Post-Test Experimental Group Standard Deviation is 4.60616 (Which is approximately double that of the Post-Test Control Group SD). In the meantime, both groups have very much different Means. Put another way, Post-Test Control Group Mean is 14.5625 but Post-Test Experimental Group Mean is 51.5938. This shows a drastic change in the performance of the Experimental Group

TABLE 1.

DESCRIPTIVE STATISTICS OF PRE-TEST CONTROL/EXPERIMENTAL GROUPS

\begin{tabular}{|l|l|l|l|l|l|l|l|}
\hline & N & Range & Minimum & Maximum & Mean & Std. Deviation & Variance \\
\hline PreCGroup & 32 & 10.00 & 10.00 & 20.00 & 14.5313 & 2.75897 \\
PreEGroup & 32 & 10.00 & 10.00 & 20.00 & 14.5625 & 2.99395 \\
Valid N (listwise) & 32 & & & & & \\
\hline
\end{tabular}

TABLE 2.

DESCRIPTIVE STATISTICS OF POST-TEST CONTROL/EXPERIMENTAL GROUPS

\begin{tabular}{|l|l|l|l|l|l|l|l|}
\hline & $\mathrm{N}$ & Range & Minimum & Maximum & Mean & Std. Deviation & Variance \\
\hline PoCGroup & 32 & 8.00 & 11.00 & 19.00 & 14.5625 & 2.29919 \\
PoEGroup & 32 & 15.00 & 43.00 & 58.00 & 51.5938 & 4.60616 \\
Valid N (listwise) & 32 & & & & & \\
\hline
\end{tabular}

Meanwhile, if we take a look at Table 3., we will notice the results based on paired t-test which showed that there was no significant difference between the performance of subjects in the Pre-test Control Group and that of the Experimental Group. The amount of Observed T with 95\% Confidence interval of the differences with 31 degree of freedom was -.111 which is by far lower than what it should be to show a meaningful difference between the performance of the Control and Experimental Groups. (To be meaningful, the amount of Observed $\mathrm{T}$ with $95 \%$ Confidence interval of the differences with 31 degree of freedom must be at least 2.040). So, it can be concluded that the difference between the two groups regarding their performance was not significant. Put another way, no superiority of one group over the other was observed. However, Table 4. (Post-test Control/Experimental groups Paired t-test), shows us a major difference between the performance of subjects in the two groups. In other words the amount of Observed $\mathrm{T}$ with $95 \%$ Confidence interval of the differences with 31 degree of freedom was -40.756 which provides a significant difference between the two groups (The Experimental Group performed by far much better that the Control Group).

TABLE 3.

PAIRED T-TEST OF PRE-TEST CONTROL/EXPERIMENTAL GROUPS

\begin{tabular}{|c|c|c|c|c|c|c|c|c|}
\hline & \multicolumn{5}{|c|}{ Paired Differences } & \multirow{3}{*}{$\mathrm{t}$} & \multirow{3}{*}{ df } & \multirow{3}{*}{$\begin{array}{l}\text { Sig. (2 } \\
\text { tailed) }\end{array}$} \\
\hline & \multirow[t]{2}{*}{ Mean } & \multirow[t]{2}{*}{ Std. Dev. } & \multirow[t]{2}{*}{$\begin{array}{l}\text { Std. Error } \\
\text { Mean }\end{array}$} & \multicolumn{2}{|c|}{$\begin{array}{l}95 \% \text { Confidence Interval of } \\
\text { the Difference }\end{array}$} & & & \\
\hline & & & & Lower & Upper & & & \\
\hline $\begin{array}{l}\text { Pair } 1 \\
\text { PreCGroup/PreEGroup }\end{array}$ & -.03125 & 1.59605 & .28214 & -.60669 & -.54419 & -.111 & 31 & .913 \\
\hline
\end{tabular}

TABLE 4.

PAIRED T-TEST OF POST-TEST CONTROL/EXPERIMENTAL GROUPS

\begin{tabular}{|c|c|c|c|c|c|c|c|c|}
\hline & \multicolumn{5}{|c|}{ Paired Differences } & \multirow{3}{*}{$\mathrm{t}$} & \multirow{3}{*}{$\mathrm{df}$} & \multirow{3}{*}{$\begin{array}{l}\text { Sig. (2- } \\
\text { tailed) }\end{array}$} \\
\hline & \multirow[t]{2}{*}{ Mean } & \multirow[t]{2}{*}{ Std. Dev. } & \multirow[t]{2}{*}{$\begin{array}{l}\text { Std. Error } \\
\text { Mean }\end{array}$} & \multicolumn{2}{|c|}{$\begin{array}{l}\text { 95\% Confidence Interval of the } \\
\text { Difference }\end{array}$} & & & \\
\hline & & & & Lower & Upper & & & \\
\hline $\begin{array}{l}\text { Pair } 1 \\
\text { PostCGroup/PostEGroup }\end{array}$ & -37.03125 & 5.13988 & .90861 & -38.88437 & -35.17813 & -40.756 & 31 & .000 \\
\hline
\end{tabular}


To be more confident, certain and sure that the treatment was the only reason for the difference made between the two groups and nothing else a second post test called "The Delayed Post-Test" was administered in which both The Control and The Experimental Group took the test for the third time with the results shown in Tables 5 and 6.

Table 5. shows that there is still a big difference between the Control and Experimental Groups' Means in the Delayed Post Test (14.3437 vs. 50.5000). Meanwhile, the Control Group Standard Deviation in the Delayed Post Test is almost half of that of the Experimental Group (2.45750 vs. 4.72468).

Meanwhile, regarding the paired t-test results gained for the Control/Experimental Groups' Delayed Post-Test (as seen in Table 6), we can see that the amount of observed $t$ is still -40.106 which means that there is still a significant difference between the two groups regarding their performance on the test results. In other words, after two weeks, still the Experimental Group had a much higher performance than the Control Group in the test given after the treatment. So, we can be more confident that the results gained are due to the treatment.

TABLE 5.

DESCRIPTIVE STATISTICS OF CONTROL/EXPERIMENTAL GROUPS’ DELAYED POST-TEST

\begin{tabular}{|l|l|l|l|l|l|l|l|}
\hline & $\mathrm{N}$ & Range & Minimum & Maximum & \multicolumn{2}{l|}{ Mean } & \multicolumn{2}{l|}{ Std. Deviation } \\
\cline { 2 - 8 } & Statistic & Statistic & Statistic & Statistic & Statistic & Std. Error & Statistic \\
\hline DPosCGroup & 32 & 9.00 & 10.00 & 19.00 & 14.3437 & .43443 \\
DPosEGroup & 32 & 17.00 & 41.00 & 58.00 & 50.5000 & .83521 \\
Valid N (listwise) & 32 & & & & & & \\
\hline
\end{tabular}

TABLE 6.

PAIRED T-TEST OF CONTROL/EXPERIMENTAL GROUPS’ DELAYED POST-TEST

\begin{tabular}{|c|c|c|c|c|c|c|c|c|}
\hline & \multicolumn{5}{|c|}{ Paired Differences } & \multirow{3}{*}{$\mathrm{t}$} & \multirow{3}{*}{ df } & \multirow{3}{*}{$\begin{array}{l}\text { Sig. (2- } \\
\text { tailed) }\end{array}$} \\
\hline & \multirow[t]{2}{*}{ Mean } & \multirow[t]{2}{*}{ Std. Dev. } & \multirow[t]{2}{*}{$\begin{array}{l}\text { Std. Error } \\
\text { Mean }\end{array}$} & \multicolumn{2}{|c|}{$\begin{array}{l}\text { 95\% Confidence Interval of the } \\
\text { Difference }\end{array}$} & & & \\
\hline & & & & Lower & Upper & & & \\
\hline $\begin{array}{l}\text { Pair } 1 \\
\text { DPosCGroup/DPosEGroup }\end{array}$ & -36.15625 & 5.09971 & .90151 & -37.99489 & -34.31761 & -40.106 & 31 & .000 \\
\hline
\end{tabular}

\section{DISCUSSION}

The research question sought to investigate the effect of explicit teaching of refusals to EFL learners. Based on the findings, it can be argued that instruction has a significantly affected participants' use of refusal. This study seems to provide evidence supporting Schmidt's (1990) idea which regarded noticing as an important condition for acquisition. According to Schmidt, awareness is required for learning to take place and noticing is needed to input to intake. Regarding the present study, explicit teaching of grammar during different stages of the treatment leads learners notice the pragmatic aspects of language.

It could also be argued that teachers should not suffice to assume that linguistic mastery of language is the ultimate goal of foreign language instruction. Foreign language learners who are away from the real context, where they can have contact with native speakers, should be taught to make use of pragmalinguistic features of language. Such features could be incorporated into the classroom activities while making use of films, videos as well as authentic materials.

Based on the theoretical assumptions which provided the underlying foundation for the present study and the findings, further longitudinal times series research is needed to investigate the effect of the treatment in the long run and make sure whether the obtained results are due to the treatment and whether they have turned to be part of the learner's input. 


\section{APPENDIX}

Table: Instructional Targets

\begin{tabular}{|c|c|c|c|c|}
\hline $\begin{array}{l}\text { Stimulus } \\
\text { Types }\end{array}$ & $\begin{array}{l}\text { Refuser } \\
\text { Status }\end{array}$ & Refusals Strategies & Typical Expressions & Situation \\
\hline \multirow[t]{3}{*}{$\begin{array}{l}\text { Refusals to } \\
\text { Invitations }\end{array}$} & $\mathrm{L}-\mathrm{H}$ & $\begin{array}{l}\text { 1. Positive feeling } \\
\text { 2. Negative ability } \\
\text { 3. Explanation }\end{array}$ & $\begin{array}{l}\text { I'd love to (positive feeling), but I } \\
\text { can't (negative feeling), I have to work } \\
\text { (explanation). }\end{array}$ & $\begin{array}{l}\text { Refusing a teacher's/a boss's } \\
\text { invitation to a party }\end{array}$ \\
\hline & E-E & $\begin{array}{l}\text { 1. No } \\
\text { 2. Gratitude, Future } \\
\text { acceptance } \\
\text { 3. Explanation }\end{array}$ & $\begin{array}{l}\text { No (No), thanks (gratitude), maybe next } \\
\text { time (future acceptance), I need to get back } \\
\text { and work on my project (explanation). }\end{array}$ & $\begin{array}{l}\text { Refusing a friend's invitation } \\
\text { to see a movie }\end{array}$ \\
\hline & $\mathrm{H}-\mathrm{L}$ & $\begin{array}{l}\text { 1. Gratitude } \\
\text { 2. Regret } \\
\text { 3. Explanation }\end{array}$ & $\begin{array}{l}\text { Oh, thanks for the invitation (gratitude), } \\
\text { Sorry (regret), but I'm not prepared enough } \\
\text { to address the group (explanation). }\end{array}$ & $\begin{array}{l}\text { Refusing a junior student's } \\
\text { or an employee's invitation } \\
\text { to speak for a lecture }\end{array}$ \\
\hline \multirow[t]{3}{*}{$\begin{array}{l}\text { Refusals to } \\
\text { Suggestions }\end{array}$} & L-H & $\begin{array}{l}\text { 1. Negative ability, } \\
\text { Pause filler } \\
\text { 2. Explanation } \\
\text { 3. Alternative }\end{array}$ & $\begin{array}{l}\text { Well, Hmm...(pause filler), I would rather } \\
\text { not (negative ability). I had planned to take } \\
\text { another course next semester (explanation). } \\
\text { I'll take the stats after that (alternative). }\end{array}$ & $\begin{array}{l}\text { Refusing an advisor's } \\
\text { suggestion to study another } \\
\text { course }\end{array}$ \\
\hline & E-E & $\begin{array}{l}\text { 1. Pause filler } \\
\text { 2. Positive feeling } \\
\text { 3. Explanation }\end{array}$ & $\begin{array}{l}\text { Hum...(pause filler). That would be nice } \\
\text { if I had time (positive feeling). I'm tired of } \\
\text { working on it (explanation). }\end{array}$ & $\begin{array}{l}\text { Refusing a friend's } \\
\text { suggestions about a research } \\
\text { topic or to try a new design }\end{array}$ \\
\hline & $\mathrm{H}-\mathrm{L}$ & $\begin{array}{l}\text { 1. Negative ability } \\
\text { 2. Explanation } \\
\text { 3. Alternative }\end{array}$ & $\begin{array}{l}\text { Well, no (nega tive ability). Actually it's } \\
\text { very important that we review it anyway } \\
\text { (explanation). I'll change the design next } \\
\text { time (alternative). }\end{array}$ & $\begin{array}{l}\text { Refusing a student's } \\
\text { suggestion to skip the details }\end{array}$ \\
\hline \multirow[t]{3}{*}{$\begin{array}{l}\text { Refusals to } \\
\text { Offers }\end{array}$} & L-H & $\begin{array}{l}\text { 1. Ppositive feeling } \\
\text { (Negative ability), } \\
\text { 2. Gratitude } \\
\text { 3. Explanation }\end{array}$ & $\begin{array}{l}\text { It sounds like a great opportunity (positive } \\
\text { feeling), but I'm going to have to pass on it } \\
\text { (negative ability). No, Thanks (gratitude). I } \\
\text { have a number of other things I want to focus } \\
\text { on (explanation). }\end{array}$ & $\begin{array}{l}\text { Refusing a dean's offer or a } \\
\text { boss's offer }\end{array}$ \\
\hline & E-E & $\begin{array}{l}\text { 1. No } \\
\text { 2. Gratitude } \\
\text { 3. Explanation }\end{array}$ & $\begin{array}{l}\text { No (No). Thank you you're very kind } \\
\text { (gratitude). I don't have far to go and I will } \\
\text { be okay (explanation). }\end{array}$ & $\begin{array}{l}\text { Refusing a friend's offer for } \\
\text { a ride/a piece of cake }\end{array}$ \\
\hline & $\mathrm{H}-\mathrm{L}$ & $\begin{array}{l}\text { 1. Give a comfort } \\
\text { 2. Letting the } \\
\text { interlocutor off } \\
\text { the hook. }\end{array}$ & $\begin{array}{l}\text { Don't worry (give a comfort). I know it was } \\
\text { an accident (letting the interlocutor off the } \\
\text { hook). }\end{array}$ & $\begin{array}{l}\text { Refusing a cleaning lady's } \\
\text { paying for broken vase }\end{array}$ \\
\hline \multirow[t]{2}{*}{$\begin{array}{l}\text { Refusals to } \\
\text { Requests }\end{array}$} & L-H & $\begin{array}{l}\text { 1. Explanation } \\
\text { 2. Alternative } \\
\text { 3. Regret }\end{array}$ & $\begin{array}{l}\text { I have that doctor's appointment (explanation). } \\
\text { Can't Carrie (sister) do that for you? } \\
\text { (alternative). I'm sorry Mom (regret). }\end{array}$ & Refusing a mother's request \\
\hline & E-E & $\begin{array}{l}\text { 1. Regret } \\
\text { 2. Expanation } \\
\text { 3. Alternative }\end{array}$ & $\begin{array}{l}\text { I'm sorry (regret), but I need to be glued } \\
\text { to this computer until tomor row morning } \\
\text { (explanation). Perhaps someone else does not } \\
\text { have such a tight deadline (alternative). }\end{array}$ & $\begin{array}{l}\text { Refusing a friend's request } \\
\text { to use a computer }\end{array}$ \\
\hline
\end{tabular}

H-L 1. Positive feeling I'd really like to help you out (positive feeling) Refusing a junior member's
2. Regret
3. Explanation

but, sorry, I'm afraid (regret), I'm really

request to interview

strapped for time right now and can't really afford to (explanation).

$\mathrm{L}-\mathrm{H}=\mathrm{a}$ lower refuser to a higher interlocutor, $\mathrm{E}-\mathrm{E}=$ an equal refuser to an equal interlocutor, $\mathrm{H}-\mathrm{L}=\mathrm{a}$ higher refuser to a lower interlocutor (adopted from Wannaruk, 2008). 


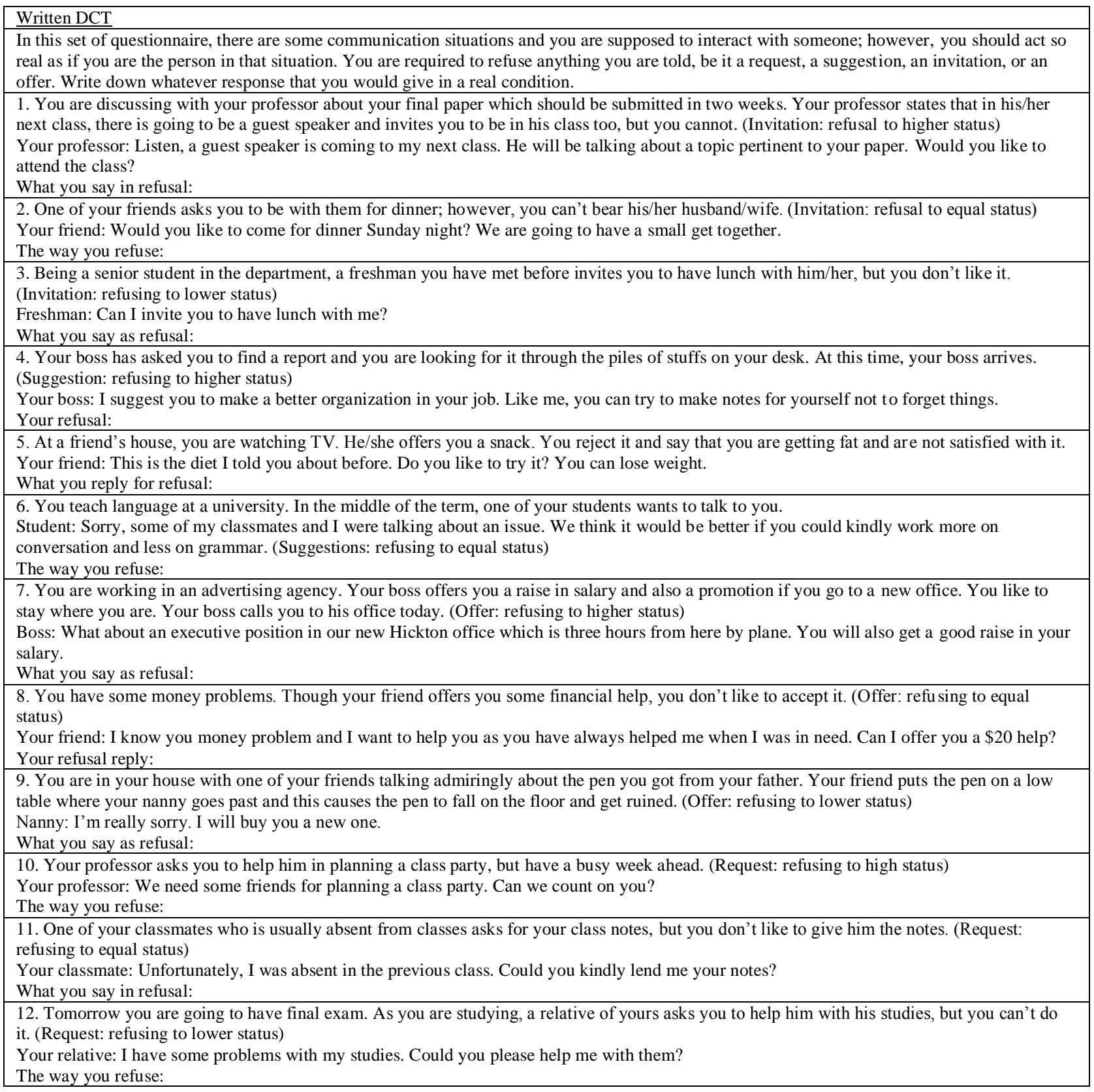

\section{Written Self-Report}

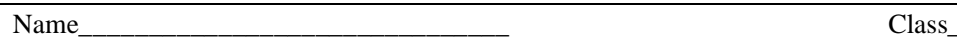

1. Do you feel any difference in your communication in English after the instruction?

Can you give some examples?

2. Do you think that such an instruction was needed? Why?

3. What is your opinion about the method used in teaching American refusals?

4. Do you think that if you are in a real conversation with an English native speaker, you can use the refusal expressions taught here? Do you think the instruction would cause a great difference? Why?

\section{REFERENCES}

[1] Kahtani, W. (2005). Refusals realizations in three different cultures: A speech act theoretically-based cross-cultural study. Journal of King Saud Univ., 18, 35-57.

[2] Bardovi-Harlig, K. (1999). Exploring the interlanguage of interlanguage pragmatics: A research agenda for acquisitional pragmatics. Language Learning, 49, 677-713.

[3] Brock, M. N., \& Nagasaka, Y. (2005). Teaching pragmatics in the EFL classroom? SURE you can! TESL Reporter, $38(1)$, 1726.

[4] Brown, P., \& Levinson, S. C. (1987). Politeness: Some universals in language usage. Cambridge: Cambridge University Press. 
[5] Duan, L. (2008). The effects of explicit and implicit instruction on appropriacy of English refusal by Chinese EFL students. Unpublished doctoral thesis. Suranaree University of Technology.

[6] Ellis, R. (2008). The study of second language acquisition. Oxford: Oxford University Press.

[7] Kasper, G., \& Rose, K. R. (2002). Pragmatic development in a second language. Oxford: Blackwell Publishing Limited.

[8] Kasper, G., \& Schmidt, R. (1996). Developmental issues in interlanguage pragmatics. Studies in Second Language Acquisition, $18,149-169$.

[9] Kasper, G. (1997). Can pragmatic competence be taught? Honolulu: University of Hawai'i, Second Language Teaching \& Curriculum Center. Retrieved March 2011, from www.nflrc.hawaii.edu/NetWorks/Nw6/

[10] Kasper, G. (2001). Classroom research on interlanguage pragmatics. In Kasper, G., \& Rose, K. (Eds.), Pragmatics and language teaching (pp. 33-60). Cambridge: Cambridge University Press.

[11] King, K. A., \& Silver, R. E. (1993). Sticking points: Effects of instruction on NNS refusal strategies. Working Papers in Educational Linguistics, 9, 47-82.

[12] Koike, D. A. (1997). Pragmatic competence and adult L2 acquisition: Speech acts interlanguage. The Modern Language Journal, 73, 279-289.

[13] Lingli, D., \& Wannaruk, A. (2010). The effects of explicit and implicit instruction in English refusals. Chinese Journal of Applied Linguistics, 33(3), 93-109.

[14] Little, D. (1996). Strategic competence and the learner's strategic control of the language learning process. Language Teaching, 29(2), 94-97.

[15] Martinez-Flor, A., \& Uso Juan, E. (2006). Pragmatic development in a second or foreign language: Some classroom techniques. Greta, 14(1 \& 2), 50-56.

[16] Morrow, K. C. (1995). The pragmatic effects of instruction on ESL learners' production of complaint and refusal speech acts. Unpublished doctoral dissertation, State University of New York at Buffalo.

[17] Nassaji, H., \& Fotos, S. (2004). Current developments in research on the teaching of grammar. Annual Review of Applied Linguistics, 24, 126-145.

[18] Rueda, Y. T. (2006). Developing pragmatic competence in a foreign language. Colombian Applied Linguistics Journal, 8, 169 182.

[19] Schmidt, R. (1990). The role of consciousness in second language learning. Applied Linguistics, 11, 129-158.

[20] Schmidt, R. (1995). Consciousness and foreign language learning: A tutorial on the role of attention and awareness in learning (pp. 1-63). In Schmidt, R. (Ed.), Attention and awareness in foreign language learning. Honolulu: University of Hawaii Press.

[21] Silva, A. J. B. (2003). The effect of instruction on pragmatic development: Teaching polite refusals in English. Second Language Studies, 22(1), 55-106.

[22] Tanaka, K. (1997). Developing pragmatic competence: A learners-as-researchers approach. TESOL Journal, 6(3), 14-18.

[23] Thomas, J. (1983). Cross-cultural pragmatic failure. Applied Linguistics, 4, 91-112.

[24] Vásquez, C., \& Sharpless, D. (2009). The role of pragmatics in the master's TESOL curriculum: Findings from a nationwide survey, TESOL Quarterly, 43(1), 5-28.

[25] Yoshimi, D. R. (2001). Explicit instruction and JFL learner's use of interactional discourse markers. In K. R. Rose \& G. Kasper (Eds.), Pragmatics in language teaching (pp. 223-244). Cambridge, UK: Cambridge University Press.

[26] Wannaruk, A. (2008). Pragmatic transfer in Thai EFL refusals. RELC Journal, 39(3), 318-337.

Majid Farahian is a lecturer in the Department of Foreign Languages, Kermanshah Branch, Islamic Azad University, Kermanshah, Iran, and at the same time, he is studying for his Ph.D. (Applied Linguistics) in Islamic Azad University, Science and Research Branch, Tehran, Iran. He has been teaching all courses related to ELT in Associate Diploma and BA levels at Islamic Azad University, Kermanshah Branch. He has had different articles on Linguistics, Teaching, and Literature in different journals.

Mehrdad Rezaee is a lecturer in the Department of Foreign Languages, Central Tehran Branch, Islamic Azad University, Tehran, Iran and at the same time, he is studying for his Ph.D. (Applied Linguistics) in Islamic Azad University, Science and Research Branch, Tehran, Iran. He has been teaching all courses related to ELT in Associate Diploma and BA levels at Islamic Azad University, Tehran Central Branch.

Afshin Gholami is a TEFL M.A student in Razi University. Kermanshah, Iran. 